\title{
Thermal Stability and Decomposition Kinetics of AgO Submicron Particles Prepared by Potassium Persulfate Oxidation
}

\author{
Hui FENG ${ }^{1}$, Wenning SHEN ${ }^{2}$, Lajun FENG ${ }^{2}$, Ali LEI ${ }^{2}$, Yanfeng GE $^{2}$ \\ ${ }^{1}$ Shaanxi Institute of Zoology, No. 88 Xingqing Road, Xi'an 710032, China \\ ${ }^{2}$ School of Materials Science and Engineering, Xi'an University of Technology, No. 5 South Jinhua Road, Xi'an 710048, \\ China \\ crossref http://dx.doi.org/10.5755/j01.ms.24.1.17052
}

Received 29 November 2017; accepted 17 July 2017

\begin{abstract}
In this study, $\mathrm{AgO}$ submicron particles for antimicrobial application were prepared by potassium persulfate oxidation. The characterization of AgO particles was performed by XRD, XPS, SEM, TEM and TGA analysis. Its decomposition kinetics was studied by Doyle mechanism equation, Coats-Redfern equation and Ozawa approximate integration. The results showed that the as-prepared powders were composed of monoclinic $\mathrm{AgO}$ and small amounts of carbonate. The average width of $\mathrm{AgO}$ particles was about $200 \mathrm{~nm}$ with a rod-like morphology. AgO submicron particles could be decomposed to be $\mathrm{Ag}_{2} \mathrm{O}$ at $123{ }^{\circ} \mathrm{C}$. When the temperature was increased to $405{ }^{\circ} \mathrm{C}, \mathrm{Ag}_{2} \mathrm{O}$ was further transformed to be $\mathrm{Ag}$. The decomposition reaction of $\mathrm{AgO}$ was controlled by Avrami-Erofeev random nucleation and subsequently growth mechanism (A1) with the apparent activation energy of $88.34 \mathrm{~kJ} / \mathrm{mol}$ and the reaction frequency factor of $4.88 \times 10^{9} \mathrm{~s}^{-1}$. Keywords: AgO, TGA, thermal properties, thermodynamic properties.
\end{abstract}

\section{INTRODUCTION}

Silver containing compounds and materials have attracted considerable interests in recent years, since silver ions exhibit strong bacteriostatic and sterilization effects as well as a broad spectrum of antimicrobial activities [1-7]. The bacteria are difficult to resist silver containing products [8]. Furthermore, the antimicrobial property of different silver containing compounds and materials is relative to silver valence states, which the higher silver valence state has led to the better sterilization effect. So far the different materials have been studied, their effects are ordered in the following sequences: $\mathrm{AgO}>\mathrm{Ag}_{2} \mathrm{O}>\mathrm{Ag}$, $\mathrm{AgNO}_{3}>\mathrm{Ag}-\mathrm{ZSM}-5>\mathrm{Ag}_{2} \mathrm{O}>$ commercial silverexchanged zeolite (granular) $>$ commercial silverexchanged zeolite (pellets) $>\mathrm{Ag}$ nanoparticles, respectively $[9,10]$. The antimicrobial effect of silver dioxide has been extensively researched recently. Chen et al. [11] and Shen et al. [12] have reported that the antimicrobial effects of $\mathrm{AgO}$ are stronger than those of $\mathrm{Ag}_{2} \mathrm{O}$. Additionally, the materials in nano and submicrosize have special physical and chemical properties, such as antimicrobial property, because of their large ratio of surface area to volume and the high fraction of surface atoms [3,13]. Thus, AgO submicron particles and nanoparticles might be important in the antimicrobial application; for instance, water treatment.

There are several methods to fabricate $\mathrm{AgO}$ particles, such as potassium persulfate oxidation [14, 15], ozone oxidation [12], chlorine oxidation [16], electrochemical process [17, 18], chemical bath deposition [19], etc. However, the thermal stability and decomposition kinetic of $\mathrm{AgO}$ bactericide vary depending on the reaction conditions, the preparation technology, the particle size

\footnotetext{
${ }^{*}$ Corresponding author. Tel.: +86-29-82312733; fax: +86-29-82312733

E-mail address: shenwenning@qq.com (W. Shen)
}

and so on $[20,21]$. Therefore, it is difficult to achieve the thermal stability law of $\mathrm{AgO}$, which restricts its wide applications.

In our study, $\mathrm{AgNO}_{3}$ and $\mathrm{K}_{2} \mathrm{~S}_{2} \mathrm{O}_{8}$ were used as precursors to prepare $\mathrm{AgO}$ submicron particles. Then the thermal stability of $\mathrm{AgO}$ submicron particles and their decomposition kinetics were determined by thermogravimetric analysis-differential thermal analysis (TGA-DTA) method. The present study is aimed to provide theoretical basis for the storage and application of $\mathrm{AgO}$ particles.

\section{MATERIALS AND METHODS}

\subsection{Materials}

$\mathrm{AgNO}_{3}(\geq 99.8 \%$ purity, Xi'an Nonferrous Metals Research Institute), $\mathrm{K}_{2} \mathrm{~S}_{2} \mathrm{O}_{8}$ and $\mathrm{KOH}(\geq 99.5 \%$ and $\geq 85.0 \%$ purity, Tianjin Tianli Chemical Reagent Co., Ltd.) were employed as reactants for the fabrication of $\mathrm{AgO}$ submicron particles. Deionized water was made in our laboratory.

\subsection{Fabrication of $\mathrm{AgO}$ submicron particles}

Potassium persulfate oxidation method was used to synthesize $\mathrm{AgO}$ submicron particles. The general procedures were as follows. $300 \mathrm{~mL}$ of $\mathrm{AgNO}_{3}$ solution with a concentration of $0.05 \mathrm{~mol} / \mathrm{L}$ was added into a $1000 \mathrm{~mL}$ three-necked flask. The $\mathrm{AgNO}_{3}$ solution was then heated in a thermostat water bath at $60{ }^{\circ} \mathrm{C}$. Subsequently, $200 \mathrm{~mL}$ of $\mathrm{K}_{2} \mathrm{~S}_{2} \mathrm{O}_{8}$ solution with a concentration of $0.225 \mathrm{~mol} / \mathrm{L}$ was added drop-wisely into $\mathrm{AgNO}_{3}$ solution under vigorous stirring. Later, $100 \mathrm{~mL}$ of $\mathrm{KOH}$ solution of $1.275 \mathrm{~mol} / \mathrm{L}$ was slowly added into the mixture. The mixture was then mixing constantly for $20 \mathrm{~min}$. After that, the solid product was obtained, followed repeatedly washing and drying at $50{ }^{\circ} \mathrm{C}$ for $6 \mathrm{~h}$. 


\subsection{Characterization}

The prepared particles were characterized by an XRD7000S X-ray diffractometer (XRD). XRD data were collected at a tube voltage of $40 \mathrm{kV}$, a tube current of $30 \mathrm{~mA}, 2$ theta of $20-80^{\circ}$, and scan speed of $10 \% \mathrm{~min}$. The $\mathrm{X}$-ray source was $\mathrm{Cu} X$-ray with a $\lambda$ of $0.15418 \mathrm{~nm}$.

The element quantivalency of Element $\mathrm{Ag}$ and $\mathrm{C}$ was analyzed by X-ray photoelectron spectroscopy (XPS). The XPS spectra were achieved using a Kratos Axis Ultra instrument. The base pressure of the analytical chamber was $10^{-9}$ Torr. Spectra were excited using monochromatic $\mathrm{AlK} \alpha(150 \mathrm{~W}, 15 \mathrm{kV}, 1486.7 \mathrm{eV})$. The pass energy was $20 \mathrm{eV}$ for narrow scanning. Binding energies were calibrated relative to the $\mathrm{C} 1 \mathrm{~s}$ peak $(284.8 \mathrm{eV})$ from hydrocarbons adsorbed on the products' surface.

The morphology and particle size of the particles were examined by a JSM-6700F scanning electron microscope (SEM) and JEM-3010 transmission electron microscope (TEM). Before SEM analysis, the sample was covered with Pt thin film. The micrographs were obtained at an accelerating voltage of $20 \mathrm{kV}$ and an accelerating current of $10 \mu \mathrm{A}$.

Thermal stability of the product was analyzed by WRT-3P trace thermobalance, using air as measuring atmosphere. The heating rates were $5^{\circ} \mathrm{C} / \mathrm{min}, 10^{\circ} \mathrm{C} / \mathrm{min}$, $15^{\circ} \mathrm{C} / \mathrm{min}$ and $20^{\circ} \mathrm{C} / \mathrm{min}$ respectively. Its corresponding tested sample amounts were $32.92 \mathrm{mg}, 40.42 \mathrm{mg}, 32.5 \mathrm{mg}$ and $32.67 \mathrm{mg}$ respectively.

\section{RESULTS AND DISCUSSION}

\subsection{Analysis of AgO submicron particles}

Fig. 1 shows the XRD pattern of $\mathrm{AgO}$ particles. All diffraction peaks observed in the obtained XRD pattern (marked with ' $\boldsymbol{\nabla}$ ') corresponded to monoclinic structure of $\mathrm{AgO}$ (JCPDS card\#89-3081). This indicated that $\mathrm{AgO}$ with a crystal structure of monoclinic system was successfully obtained.

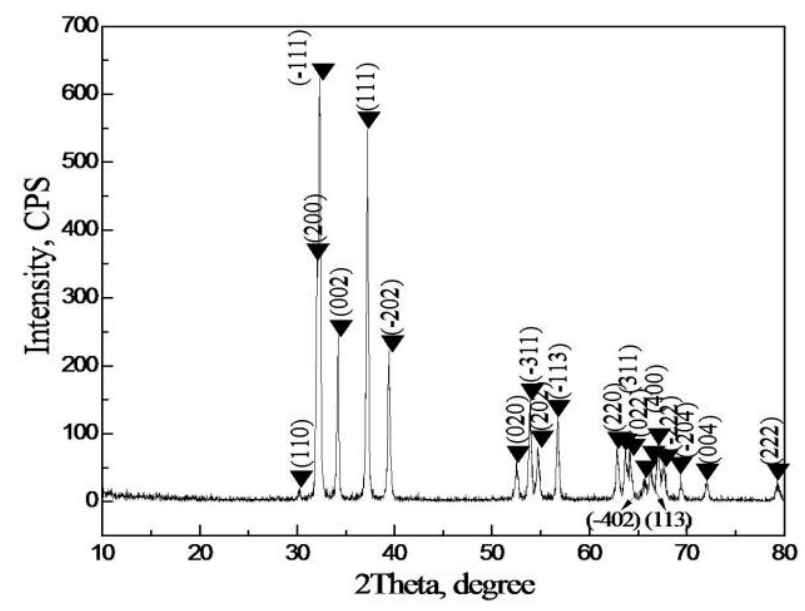

Fig. 1. XRD pattern of obtained $\mathrm{AgO}$ particles

Fig. 2 shows the XPS results of the particles. The silver electronic state in the particles can be derived from the high-resolution XPS spectrum. The core-level Ag 3d spectrum for the particles was broad, the asymmetric peaks at $374.1 \mathrm{eV}$ and $368.0 \mathrm{eV}$, which were easily appointed to core-level $\quad \mathrm{Ag}_{3} \mathrm{~d}_{3 / 2}$ and $\mathrm{Ag} 3 \mathrm{~d}_{5 / 2}$ photoemissions, respectively.

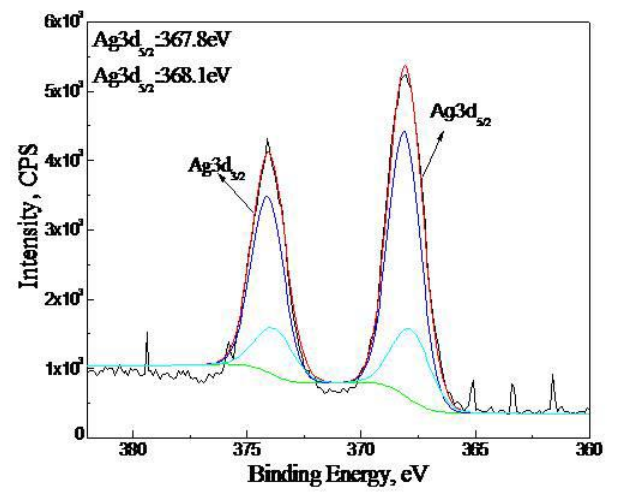

Fig. 2. XPS Ag3d spectrum for obtained AgO particles

The high-resolution $\mathrm{Ag} 3 \mathrm{~d}_{5 / 2}$ spectrum was decomposed into two individual component peaks. This indicated that the element silver in the particles was in two forms. The peak at $368.1 \mathrm{eV}$ corresponded to $\mathrm{AgO}$ [22], while the peak at $367.7 \mathrm{eV}$ was carbonate containing silver. Spectroscopic evidence for surface carbonate species was detected in the $\mathrm{O} 1 \mathrm{~s}$ and $\mathrm{C} 1 \mathrm{~s}$ spectra $(\mathrm{O} 1 \mathrm{~s}=531.5 \mathrm{eV}, \mathrm{C} 1 \mathrm{~s}=288.7 \mathrm{eV}$, Fig. 3).
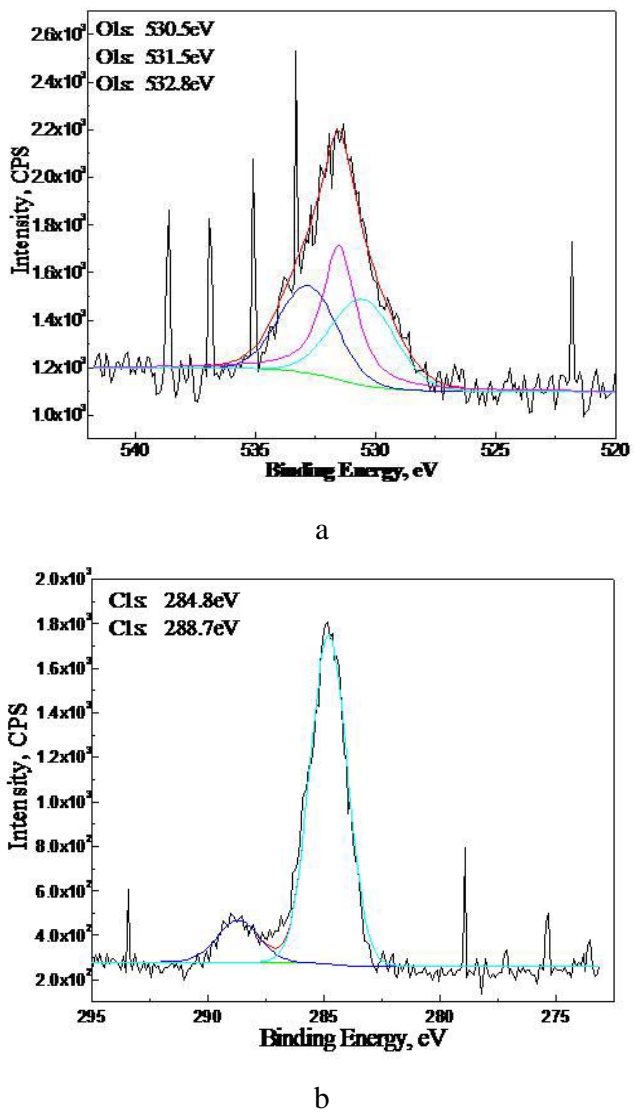

Fig. 3. XPS spectra for obtained $\mathrm{AgO}$ particles: $\mathrm{a}$-of $\mathrm{O} 1 \mathrm{~s}$; $\mathrm{b}-\mathrm{C} 1 \mathrm{~s}$

In addition, the peak at $532.8 \mathrm{eV}$ was from the hydroxyl or adsorbed water on the surface of AgO powders. The formation of carbonate was from the reaction of surface oxygen atoms with atmospheric $\mathrm{CO}_{2}$, which was a distinguishing feature common to all silver oxide [18]. 
This result showed that the particles were composed of $\mathrm{AgO}$ and small amounts of carbonate. Since carbonate was just formed on the surface of $\mathrm{AgO}$, its content was too small to be detected by XRD.

Fig. 4 shows the SEM image and TEM micrograph of $\mathrm{AgO}$ particles. It can be seen that, the particle has a flakelike morphology. The average width and length of the particles are about $200 \mathrm{~nm}$ and $500 \mathrm{~nm}$, respectively.

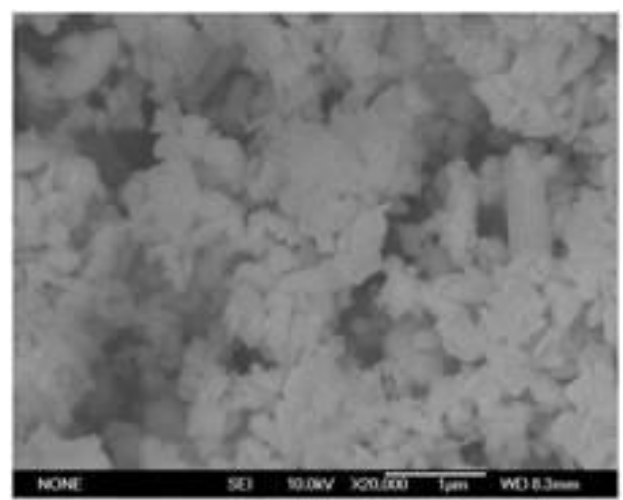

a

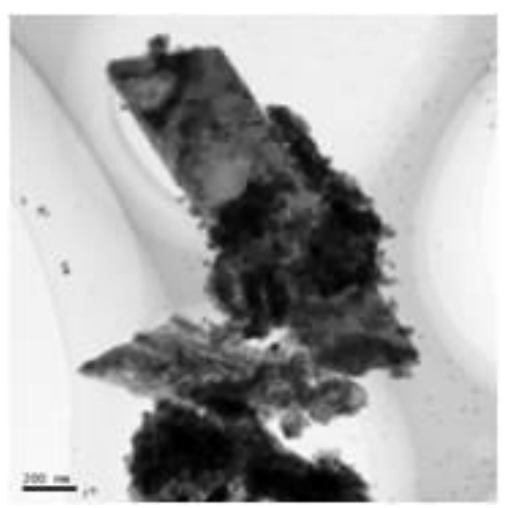

b

Fig. 4. $a-$ SEM image; $b$ - TEM micrograph of obtained AgO particles

\subsection{Thermal stability analysis of AgO submicron particles}

Fig. 5 shows the results of TGA for the $\mathrm{AgO}$ submicron particles.

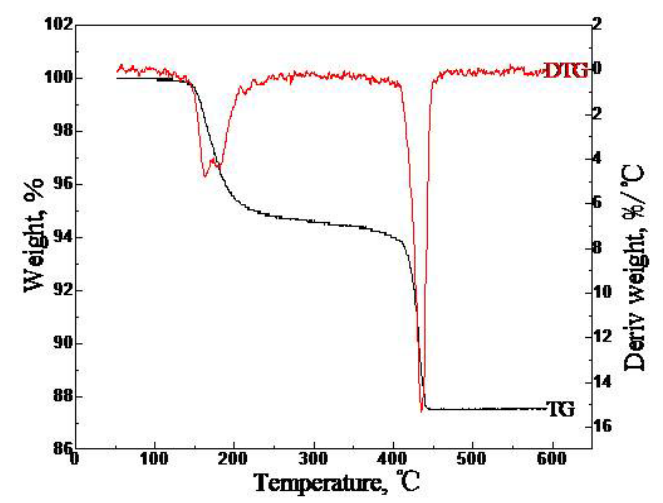

Fig. 5. TGA-DTA curves of obtained $\mathrm{AgO}$ particles at a heating rate of $15{ }^{\circ} \mathrm{C} / \mathrm{min}$

Two peaks of weight loss in the dynamic TGA curve were observed in the whole temperature programming process. AgO was decomposed in two steps. The first peak in the TGA curve was located between $123{ }^{\circ} \mathrm{C}$ and $226^{\circ} \mathrm{C}$. The weight loss percentage was about $6.18 \%$. Since $\mathrm{AgO}$ can be decomposed into $\mathrm{Ag}_{2} \mathrm{O}$ and release $\mathrm{O}_{2}$, which is represented as follows

$4 \mathrm{AgO}=2 \mathrm{Ag}_{2} \mathrm{O}+\mathrm{O}_{2} \uparrow$.

According to Eq. 1, the theoretical weight loss was calculated to be $6.46 \%$, which was consistent with theoretical value. $\mathrm{AgO}$ was decomposed into $\mathrm{Ag}_{2} \mathrm{O}$. The second stage of weight loss was in the range of $413 \sim 452^{\circ} \mathrm{C}$. It could be resulted from the decomposition of $\mathrm{Ag}_{2} \mathrm{O}$ into $\mathrm{Ag}$. Its thermo-gravimeteric loss percentage is $6.995 \%$. The decomposition of $\mathrm{Ag}_{2} \mathrm{O}$ is expressed as follows:

$2 \mathrm{Ag}_{2} \mathrm{O}=4 \mathrm{Ag}+\mathrm{O}_{2} \uparrow$.

The theoretical mass loss caused by $\mathrm{O}_{2}$ release is $6.9 \%$, which accords with experimental loss value. It confirmed the hypothesis of the decomposition of $\mathrm{Ag}_{2} \mathrm{O}$ into Ag. Thus, as a bactericide for water treatment, $\mathrm{AgO}$ particles must be used and store in temperature lower than $100{ }^{\circ} \mathrm{C}$.

\subsection{Decomposition kinetic analysis of AgO decomposition}

Based on non-isothermal reaction kinetics theory [23], under linear temperature increase condition, the kinetic equation for the decomposition of solid matter is represented as:

$\beta \cdot \frac{d \alpha}{d T}=A \cdot e^{-\frac{E}{R T}} \cdot f(\alpha)$,

where $\alpha$ is the decomposition fraction at temperature $T$, $f(\alpha)$ the mechanism function of decomposition kinetics, $A$ the frequency factor $\left(\mathrm{s}^{-1}\right), E$ the activation energy $(\mathrm{J} / \mathrm{mol})$, $T$ the temperature for decomposition reaction, and $\beta$ the linear heating rate $\left({ }^{\circ} \mathrm{C} / \mathrm{min}\right)$.

The non-isothermal kinetics of thermal decomposition of $\mathrm{AgO}$ into $\mathrm{Ag}_{2} \mathrm{O}$ was studied using single TG curve. Firstly, Doyle mechanism equation was adopted, which is shown as follows [24, 25]:

$\ln F(\alpha)=\ln \frac{A E}{\beta R}-5.3305-1.052 \frac{E}{R} \cdot \frac{1}{T}$,

where,

$F(\alpha)=\int_{0}^{\alpha} \frac{d \alpha}{f(\alpha)}$.

As shown in Eq. 4, there is a linear relationship between the $\ln F(\alpha)$ and $(1 / T)$. Ten functions of most commonly used mechanisms of solid state process (Table 1) [25] were separately substituted into equation 4 , and the linear correlation coefficient $(r)$ was obtained by least square method. Meanwhile, the activation energy $(E)$ and reaction frequency factor $(A)$ were calculated from the slope and intercept of straight line respectively.

To compare the results above, Coats-Redfern equation (Eq. 5) was used to estimate the kinetic parameters [24].

$\ln \frac{F(\alpha)}{T^{2}}=\ln \left[\frac{A R}{E \beta}\left(1-\frac{2 R T}{E}\right)\right]-\frac{E}{R} \cdot \frac{1}{T}$. 
Table 1. Most frequently used mechanisms of solid state process

\begin{tabular}{|c|c|c|c|}
\hline Mechanism & Symbol & $f(\alpha)$ & $F(\alpha)$ \\
\hline $1-$ dimensional diffusion & $\mathrm{D} 1$ & $0.5 / \alpha$ & $\alpha^{2}$ \\
\hline 2-dimensional diffusion (Valensi eqution) & $\mathrm{D} 2$ & {$[-\ln (1-\alpha)]^{-1}$} & $\alpha+(1-\alpha) \ln (1-\alpha)$ \\
\hline $3-$ dimensional diffusion (sphere. Jander equation) & $\mathrm{D} 3$ & $1.5(1-\alpha)^{2 / 3}\left[1-(1-\alpha)^{1 / 3}\right]^{-1}$ & {$\left[1-(1-\alpha)^{1 / 3}\right]^{2}$} \\
\hline $3-$ dimensional diffusion (cylinder, G-B equation) & $\mathrm{D} 4$ & $1.5\left[(1-\alpha)^{-1 / 3}-1\right]^{-1}$ & $(1-2 \alpha / 3)-(1-\alpha)^{2 / 3}$ \\
\hline $2-$ dimensional phase boundary reaction & $\mathrm{R} 2$ & $2(1-\alpha)^{1 / 2}$ & $1-(1-\alpha)^{1 / 2}$ \\
\hline 3-dimensional phase boundary reaction & $\mathrm{R} 3$ & $3(1-\alpha)^{2 / 3}$ & $1-(1-\alpha)^{1 / 3}$ \\
\hline Nucleation and nuclei growth (Avrami-Erofeev equation, $\mathrm{n}=1)$ & $\mathrm{A} 1$ & $1-\alpha$ & $-\ln (1-\alpha)$ \\
\hline Nucleation and nuclei growth (Avrami-Erofeev equation, $\mathrm{n}=1.5)$ & $\mathrm{A} 1.5$ & $1.5(1-\alpha)[-\ln (1-\alpha)]^{1 / 3}$ & {$[-\ln (1-\alpha)]^{2 / 3}$} \\
\hline Nucleation and nuclei growth (Avrami-Erofeev equation, $\mathrm{n}=2)$ & $\mathrm{A} 2$ & $2(1-\alpha)[-\ln (1-\alpha)]^{1 / 2}$ & {$[-\ln (1-\alpha)]^{1 / 2}$} \\
\hline Nucleation and nuclei growth (Avrami-Erofeev equation, $\mathrm{n}=3)$ & $\mathrm{A} 3$ & $3(1-\alpha)[-\ln (1-\alpha)]^{2 / 3}$ & {$[-\ln (1-\alpha)]^{1 / 3}$} \\
\hline
\end{tabular}

If the value of $(2 R T / E)$ changes a little bit with the temperature, it can be considered as constant in temperature programming process. Then $\ln \left(F(\alpha) / T^{2}\right)$ is a linear function for $(1 / T)$. Ten functions of most frequently used mechanisms of solid state process (Table 1) were separately substituted into Eq. 5, and the linear correlation coefficient $(r)$ was obtained by least square method. Subsequently, the activation energy was calculated from the straight line slope, and the frequency factor was obtained from the intercept at the mean temperature of decomposition.

It is reasonable to directly obtain the kinetic parameters of the thermal decomposition from the experimental data of $\alpha$ and $T$ by adopting above two integration methods, since they can avoid the error introduced by the calculation of $\mathrm{d} \alpha / \mathrm{d} T$. The experimental data of $\alpha$ and corresponding $T$ for the decomposition of $\mathrm{AgO}$ into $\mathrm{Ag}_{2} \mathrm{O}$ heated at heating rate of $15^{\circ} \mathrm{C} / \mathrm{min}$ are shown in Fig. 6. Using Doyle mechanism equation and Coats-Redfern equation, the data in Fig. 6 were separately substituted into Eq. 4 and Eq. 5, and the results are shown in Table 2 and Table 3 respectively.

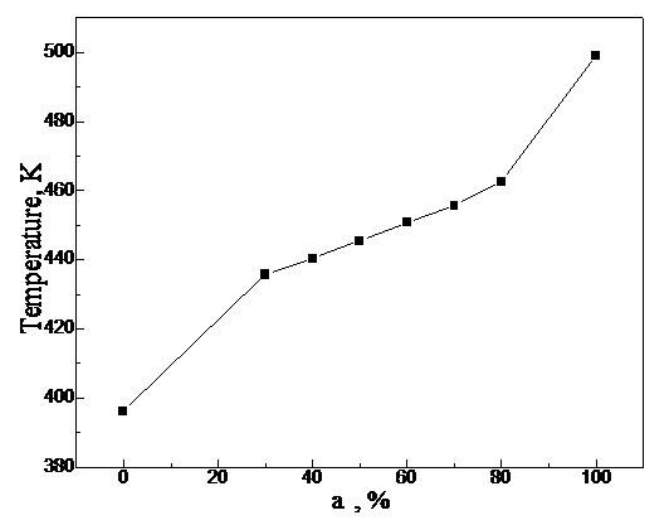

Fig. 6. $T$ versus $\alpha$ in the decomposition of obtained $\mathrm{AgO}$ at a heating rate of $15^{\circ} \mathrm{C} / \mathrm{min}$

In general, the linear correlation was used to determine the decomposition mechanism. If the mechanism function $(F(\alpha))$ might reflect the real situation of decomposition accurately, the linear correlation was better. As shown in Table 2 and Table 3, the results from Doyle mechanism equation and Coats-Redfern equation are not quite different. Among the fitting results, the maximum value of linear correlation coefficient is 0.99095 and the minimum value of standard deviation is 0.0012 , corresponding to the mechanism of nucleation and nuclei growth (Avrami-
Erofeev equation, $\mathrm{n}=1 ; \mathrm{Al}$ ). Thus, the decomposition reaction of $\mathrm{AgO}$ submicron particles prepared by potassium persulfate oxidation obeys A1 mechanism.

Table 2. Fitted results of solid state reaction mechanisms for decomposition of $\mathrm{AgO}$ from Doyle equation

\begin{tabular}{|c|c|c|c|c|}
\hline Mechanism & $E, \mathrm{~kJ} / \mathrm{mol}$ & $A, \mathrm{~s}^{-1}$ & $r$, a.u. & $s$, a.u. \\
\hline D1 & 114.587 & $2.19 \times 10^{12}$ & 0.95912 & 0.0873 \\
\hline D2 & 131.757 & $1.55 \times 10^{14}$ & 0.97169 & 0.0791 \\
\hline D3 & 153.406 & $1.75 \times 10^{16}$ & 0.98343 & 0.0622 \\
\hline D4 & 138.897 & $2.68 \times 10^{14}$ & 0.97626 & 0.0734 \\
\hline R2 & 71.386 & $2.06 \times 10^{7}$ & 0.97854 & 0.0175 \\
\hline R3 & 76.703 & $6.14 \times 10^{7}$ & 0.98343 & 0.0012 \\
\hline A1 & 88.343 & $4.88 \times 10^{9}$ & 0.99095 & 0.0012 \\
\hline A1.5 & 58.869 & $1.96 \times 10^{6}$ & 0.99095 & 0.0050 \\
\hline A2 & 44.152 & $4.27 \times 10^{4}$ & 0.99095 & 0.0028 \\
\hline A3 & 29.434 & $1.05 \times 10^{3}$ & 0.99095 & 0.0155 \\
\hline
\end{tabular}

Table 3. Fitted results of solid state reaction mechanisms for decomposition of $\mathrm{AgO}$ from Coats-Redfern method

\begin{tabular}{|c|c|c|c|c|}
\hline Mechanism & $E, \mathrm{~kJ} / \mathrm{mol}$ & $A, \mathrm{~s}^{-1}$ & $r$, a.u. & $s$, a.u. \\
\hline D1 & 113.08 & $1.43 \times 10^{12}$ & 0.95349 & 0.0878 \\
\hline D2 & 131.15 & $1.33 \times 10^{14}$ & 0.96827 & 0.0796 \\
\hline D3 & 153.92 & $2.05 \times 10^{16}$ & 0.98168 & 0.0626 \\
\hline D4 & 138.66 & $2.57 \times 10^{14}$ & 0.97353 & 0.0739 \\
\hline R2 & 67.635 & $5.26 \times 10^{6}$ & 0.97331 & 0.0177 \\
\hline R3 & 73.229 & $1.81 \times 10^{7}$ & 0.97966 & 0.0158 \\
\hline A1 & 85.432 & $1.90 \times 10^{9}$ & 0.98915 & 0.0114 \\
\hline A1.5 & 54.467 & $3.42 \times 10^{5}$ & 0.98805 & 0.0051 \\
\hline A2 & 38.985 & $4.27 \times 10^{3}$ & 0.98680 & 0.0029 \\
\hline A3 & 23.502 & 49.916 & 0.98364 & 0.0013 \\
\hline
\end{tabular}

Based on the determined function model of $\mathrm{A} 1$ mechanism, the decomposition kinetic parameters of $\mathrm{AgO}$ particles were calculated by employing Doyle mechanism equation, which has better linear correlation. The obtained apparent activation energy and the reaction frequency factor were $88.34 \mathrm{~kJ} / \mathrm{mol}$ and $4.88 \times 10^{9} \mathrm{~s}^{-1}$ respectively. For the obtained activation energy, the value of $(E / R T)$ was in the range of $21.17 \sim 26.88$ at the decomposition temperature, agreeing with the assumption of $20 \leq(E / R T) \leq 60$ for Doyle mechanism equation. This proved that the use of Doyle mechanism equation to study the decomposition kinetics of $\mathrm{AgO}$ was reasonable. The dynamical equation for the decomposition of $\mathrm{AgO}$ into $\mathrm{Ag}_{2} \mathrm{O}$ is as follows:

$-\frac{d \alpha}{d t}=4.88 \times 10^{9} \times e^{-\frac{88.34 \times 10^{3}}{R T}} \times(1-\alpha)$.

To further confirm the rationality of the determined A1 
mechanism, Ozawa approximate integration was employed to calculate the decomposition kinetic parameters of $\mathrm{AgO}$. The calculation of activation energy by Ozawa approximate integration does not involve the selection of mechanism functions, avoiding the error caused by choosing decomposition mechanism.

Ozawa equation [26]:

$\lg \beta=\lg \frac{A E}{R G(\alpha)}-2.315-0.4567 \frac{E}{R T}$,

where

$G(\alpha)=\int_{0}^{\alpha} \frac{d \alpha}{f(\alpha)}=\frac{A}{\beta} \int_{0}^{T} e^{-\frac{E}{R T}} d T$.

Since the value of $G(\alpha)$ changes very little with the temperature, it can be regarded as constant during temperature programming. Thus, there has a linear relationship between $\lg \beta$ and $(1 / T)$ at different decomposition fraction. The straight slope can be obtained by linear fitting. Subsequently, the apparent activation energy at different decomposition fraction can be derived from the slope.

$\mathrm{AgO}$ submicron particles were separately heated at the rate of $5,10,15,20^{\circ} \mathrm{C} / \mathrm{min}$ to obtain the TG curves. Based on the TG curves, different decomposition fraction and its corresponding temperature are shown in Fig. 7. At the same decomposition fraction, the values of $\lg \beta$ and $T$ in Fig. 7 were substituted into equation, and the results are shown in Table 4.

Table 4. Activation energy of $\mathrm{AgO}$ decomposition obtained from Ozawa method under different $\alpha$

\begin{tabular}{|c|c|c|c|c|c|c|}
\hline$\alpha$ & $30 \%$ & $40 \%$ & $50 \%$ & $60 \%$ & $70 \%$ & $80 \%$ \\
\hline $\begin{array}{c}E, \\
\mathrm{~kJ} / \mathrm{mol}\end{array}$ & 87.53 & 82.64 & 84.42 & 82.53 & 86.54 & 84.38 \\
\hline$r$, a.u. & 0.99455 & 0.99297 & 0.98061 & 0.98617 & 0.98894 & 0.95025 \\
\hline
\end{tabular}

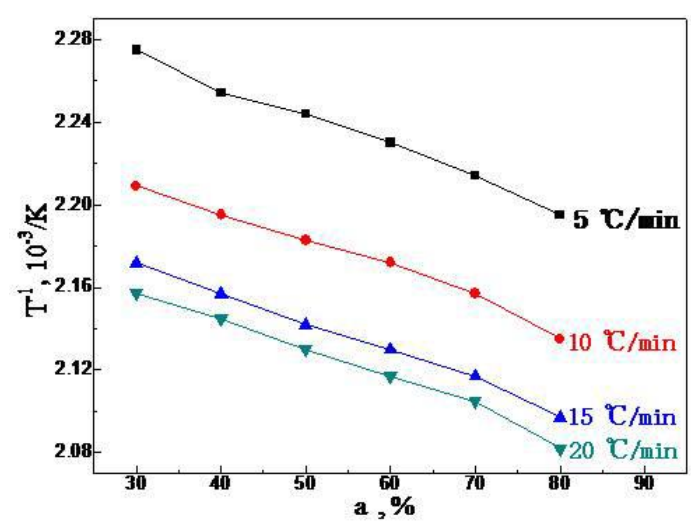

Fig. 7. $T$ versus $\alpha$ in the decomposition of obtained $\mathrm{AgO}$ at different heating rate

Among the apparent activation energy in Table 2, Table 3 and Table 4, only the activation energy derived from A1 mechanism better matches those for different decomposition fraction. This indicated the validity of A1 mechanism was obtained from Doyle equation and CoatsRedfern equation. Thus, the decomposition of $\mathrm{AgO}$ particles prepared by potassium persulfate oxidation was a process in which the nucleation and subsequent growth take place concurrently. Since heat from outside environment was adsorbed, the temperature of the lattice points in a monoclinic lattice increased. The increase of temperature intensified the vibration of the lattice points, leading to the formation of local reaction center which caused the decomposition of AgO. Subsequently, the silver oxide phase nucleated, and the dispersed crystal nucleus grew simultaneously, accelerating the decomposition of $\mathrm{AgO}$ crystal. In other words, the whole decomposition of $\mathrm{AgO}$ was a process in which the monoclinic structure of $\mathrm{AgO}$ was destroyed by the breaking of $\mathrm{Ag}-\mathrm{O}-\mathrm{Ag}$ chemical bonds and the ultimate phase of $\mathrm{Ag}_{2} \mathrm{O}$ was formed.

\section{CONCLUSIONS}

High crystallized $\mathrm{AgO}$ submicron particles with a rodlike shape were fabricated by chemical precipitation method using $\mathrm{K}_{2} \mathrm{~S}_{2} \mathrm{O}_{8}$ as oxidation in the present study. $\mathrm{AgO}$ submicron particles were decomposed to be $\mathrm{Ag}_{2} \mathrm{O}$ at $123{ }^{\circ} \mathrm{C}$. When the temperature was increased to $405^{\circ} \mathrm{C}$, $\mathrm{Ag}_{2} \mathrm{O}$ was further transformed to be $\mathrm{Ag}$. This suggested that $\mathrm{AgO}$ submicron particles were unstable up to the temperature of $123{ }^{\circ} \mathrm{C}$. The decomposition reaction of $\mathrm{AgO}$ obeyed random nucleation and subsequent nuclei growth mechanism (Avrami-Erofeev equation, $n=1$ ) with an apparent activation energy of $88.34 \mathrm{~kJ} / \mathrm{mol}$ and a reaction frequency factor of $4.88 \times 10^{9} \mathrm{~s}^{-1}$. The corresponding kinetic equation of $\mathrm{AgO}$ decomposition is expressed as

$-\frac{d \alpha}{d t}=4.88 \times 10^{9} \times e^{-\frac{88.34 \times 10^{3}}{R T}} \times(1-\alpha)$.

Based on the obtained results, it can be concluded that $\mathrm{AgO}$ submicron particles prepared by potassium persulfate oxidation should be stored and employed under $120^{\circ} \mathrm{C}$ to play the best bactericidal effect.

\section{Acknowledgments}

This work was supported financially by Key Project of Agricultural Science and Technology Innovation of Shaanxi Province (2015NY060), Key Laboratory Project of Education Department of Shaanxi Province (No. 15JS080), Key Programe-Scientific Research Project of Education Department of Shaanxi Province for 2018, Science and Technology Co-ordination \& Innovation Key Laboratory Project of Shaanxi Province (2014SZS09-Z02) and Program of Shaanxi Academy of Sciences (2016K24).

\section{REFERENCES}

1. Mirzajani, F., Ghassempour, A., Aliahmadi, A., Esmaeili, M.A. Antibacterial Effect of Silver Nanoparticles on Staphylococcus Aureus Research in Microbiology 16 2011: pp. $542-549$. https://doi.org/10.1016/j.resmic.2011.04.009

2. Panacek, A., Kolar, M., Vecerova, R., Prucek, R., Soukupova, J., $\quad$ Krystof, V., $\quad$ Hamal, P., $\quad$ Zboril, R., Kvitek, L. Antifungal Activity of Silver Nanoparticles against Candida spp Biomaterials 30 2009: pp. $6333-6340$.

https://doi.org/10.1016/j.biomaterials.2009.07.065 
3. Martinez-Gutierrez, F., Olive, P.L., Banuelos, A., Orrantia, E., Nino, N., Sanchez, E.M., Ruiz, F., Bach, H., Av-Gay, Y. Synthesis, Characterization, and Evaluation of Antimicrobial and Cytotoxic Effect of Silver and Titanium Nanoparticles Nanomedicine, Nanotechnology, Biology, and Medicine 6 2010: pp. 681-688.

https://doi.org/10.1016/j.nano.2010.02.001

4. Hernandez-Sierra, J.F., Ruiz, F., Pena, D.C.C., Martinez-Gutierrez, F., Martinez, A.E., Guillen, A. de J.P., Tapia-Perez, H., Castanon, G.M. The Antimicrobial Sensitivity of Streptococcus Mutans to Nanoparticles of Silver, Zinc Oxide, and Gold Nanomedicine, Nanotechnology, Biology, and Medicine 4 2008: pp. 237-240.

https://doi.org/10.1016/j.nano.2008.04.005

5. Gangadharan, D., Harshvardan, K., Gnanasekar, G., Dixit, D., $\quad$ Popat, K.M., $\quad$ Anand, P.S. Polymeric Microspheres Containing Silver Nanoparticles as a Bactericidal Agent for Water Disinfection Water Research 44 2010: pp. 5481-5487.

https://doi.org/10.1016/j.watres.2010.06.057

6. Shen, W., Feng, L., Feng, H., Kong, Z., Guo, M. Ultrafine Silver (II) Oxide Particles Decorated Porous Ceramic Composites for Water Treatment Chemical Engineering Journal 175 2011: pp. 592-599. https://doi.org/10.1016/j.cej.2011.09.121

7. Shen, W., Feng, L., Feng, H., Lei, A. Divalent Silver Oxide-Diatomite Hybrids: Synthesis, Characterization and Antibacterial Activity Ceramics International 39 2013: pp. 5013-5024. https://doi.org/10.1016/j.ceramint.2012.11.099

8. Rai, M., Yadav, A., Gade, A. Silver Nanoparticles as a New Generation of Antimicrobials Biotechnology Advances 27 2009: pp. 76-83.

https://doi.org/10.1016/j.biotechadv.2008.09.002

9. Yang, H., Wang, K., Ding, X., Zhou, G., Ge, M. Study on Relationship between Antibacterial Property and Silver Ions in Inorganic Antibacterial Powders Journal of Chinese Ceramics Society 30 2002: pp. 585-588 (in Chinese).

10. Lalueza, P., Monzon, M., Arruebo, M., Santamaria, J. Bactericidal Effects of Different Silver-containing Materials Materials Research Bulletin 46 2011: pp. 270-2076. https://doi.org/10.1016/j.materresbull.2011.06.041

11. Chen, K., Li, Q., Jiao, L., Zhou, G. Preparation of Nanodivalent Silver Powder and its Sterilization Properties Journal of East China University of Science and Technology (Natural Science Edition) 34 2008: pp. 86-90.

12. Shen, W., Feng, L., Kong, Z., Feng, H. Ultrafine Silver Peroxide Powders Prepared by Ozone Oxidization Method and its Antibacterial Property Acta Chimica Sinica 69 2011: pp. 277-283 (in Chinese).

13. Shahverdi, A.R., Fakhimi, A., Shahverdi, H.R., Minaian, S. Synthesis and Effect of Silver Nanoparticles on the Antibacterial Activity of Different Antibiotics against Staphylococcus aureus and Escherichia coli Nanomedicine: Nanotechnology Biology and Medicine 3 2007: pp. $168-171$. https://doi.org/10.1016/j.nano.2007.02.001

14. Li, Q., Chen, K., Jiao, L., Zhou, G. The Preparation of the Dispersed Liquid of Nanometer Bivalent Silver Oxide Water Purification Technology 27 2008: pp. 12-15 (in Chinese).

15. Shen, W., Feng, L., Lei, A., Kong. Z. Preparation of Ultra Silver Peroxide Powder and Characterization Rare Metal Materials and Engineering 40 2011: pp. 31-35 (in Chinese).

16. Zhang, Y. The Synthesis of Nano-AgO and its Electrochemical Performance. M.S. Thesis, Beijing University of Chemical Technology, Beijing, 2007 (in Chinese).

17. Jordan, M.B., Feng, Y., Burkett, S.L. Development of Seed Layer for Electrodeposition of Copper on Carbon Nanotube Bundles Journal of Vacuum Science \& Technology B 33 2015: pp. 021202. https://doi.org/10.1116/1.4907164

18. Waterhouse, G.I.N., Metson, J.B., Bowmaker, G.A. Synthesis, Vibrational Spectra and Thermal Stability of $\mathrm{Ag}_{3} \mathrm{O}_{4}$ and Related $\mathrm{Ag}_{7} \mathrm{O}_{8} \mathrm{X}$ Salts $\left(\mathrm{X}=\mathrm{NO}_{3}{ }^{-}, \mathrm{ClO}_{4}{ }^{-}, \mathrm{HSO}_{4}{ }^{-}\right)$ Polyhedron 26 2007: pp. 3310-3322. https://doi.org/10.1016/j.poly.2007.03.006

19. Kocareva, T., Grozdanov, I., Pejova, B. Ag ang AgO Thin Film Formation in $\mathrm{Ag}^{+}$- Triethanolamine Solutions Materials Letters 47 2001: pp. 319-323. https://doi.org/10.1016/S0167-577X(00)00257-3

20. Yue, L., Shui, M., Xu, Z. The Crystal Structure of Ultrafine $\mathrm{CaCO}_{3}$ and its Thermal Decomposition Chemical Journal of Chinese Universities 2000: pp. 1555-1559 (in Chinese).

21. Smith, D.F., Brown, C. Aging in Chemically Prepared Divalent Silver Oxide Electrodes for Silver/zinc Reserve Batteries Journal of Power Sources 96 2001: pp. $121-127$. https://doi.org/10.1016/S0378-7753(00)00679-0

22. Gerenser, L.J. Photoemission Investigation of Silver/poly(ethylene terephthalate) Interfacial Chemistry: the Effect of Oxygen-plasma Treatment Journal Vacuum Science \& Technology A 8 1990: pp. 3682-3691. http://dx.doi.org/10.1116/1.576480

23. Hu, R., Shi, Q. Thermal Analysis Kinetics. Science Press, Beijing, 2001: pp. 230-238 (in Chinese).

24. Li, F., He, J., Du, Y., Evans, D.G., Wang, Z., Duan, X. Study on the Preparation and Non-isothermal Kinetics of Thermal Decomposition of $\alpha$-zirconium Phosphate Journal of Inorganic Chemistry 15 1999: pp. 55-60 (in Chinese).

25. Chu, S. Thermal Analysis of Explosives. Science Press, Beijing, 1994: pp. 159-165 (in Chinese).

26. Li, Q., Chen, S., Yao, P., Wei, G., Qu, Y. Thermal Decomposition Mechanism of the Nano-BaTiO 3 Formation Acta Physico-Chimica Sinica 16 2000: pp. 170-174 (in Chinese). 